\title{
Panel seeks cut and delay in international fusion project
}

Washington. An international collaboration aimed at proving that fusion power can work should be radically scaled down to reduce its construction cost from between $\$ 10$ and $\$ 13$ billion to less than $\$ 4$ billion, according to a panel appointed by President Bill Clinton to assess the US fusion programme.

But as the United States' partners in the International Thermonuclear Experimental Reactor (ITER) - Russia, Europe and Japan - reeled from the panel's conclusions, congressional sources warned that the United States was unlikely to support fusion research, even at the reduced level recommended by the panel.

The panel is a subgroup of the President's Committee of Advisors on Science and Technology, and is chaired by John Holdren of the University of California at Berkeley. It says in a draft report that there is no realistic chance of the US fusion budget growing from its current annual level of $\$ 370$ million, but argues that a stable budget of $\$ 320$ million could preserve "the most indispensable elements" of the programme.

The draft calls on the administration to "immediately open negotiations with the ITER partners" to scale down the planned international facility from one that could sustain fusion continuously to one which could manage it for 100 seconds at a time. It says, too, that construction should be delayed for three years.

The panel also suggests a domestic programme that would enable the Princeton Plasma Physics Laboratory (PPPL) to extend the life of its Tokamak Fusion Test
Reactor (TFTR) for three years. US officials would then reassess the need for its replacement, the Tokamak Physics Experiment.

Responding to the draft report, circulated last week in what may be a vain attempt to influence this year's budget process in Congress, Anne Davies, head of fusion at the Department of Energy, said she favoured its recommendations. But she added: "the first issue for the administration to decide is whether it can afford to put $\$ 320$ million a year into fusion for ten years".

The main issue in ITER, she said, was that the United States would have to "cap" its contribution. Scaling back the programme is not the only way to do this; alternatives include attracting more partners, or getting the country that eventually hosts the facility to pay a larger share, said Davies.

Robert Aymar, director of ITER, declined to comment on the Holdren report, saying that it is only a draft. But Davies claims that the international partners are "very upset" by the report.

Ron Davidson, director of PPPL, said he was "very encouraged" by the Holdren report, which, he said, "made a very strong argument that the fusion effort should be sustained at $\$ 320$ million". But congressional staff say the report had come too late to save the fusion programme.

The House Appropriations Committee has already agreed to slash this year's fusion budget to $\$ 229$ million (see Nature 375, 662; 1995). There are few signs that the relevant Senate subcommittee will try to restore much of that cut.

Colin Macilwain

\section{The US route to a working fusion power plant}

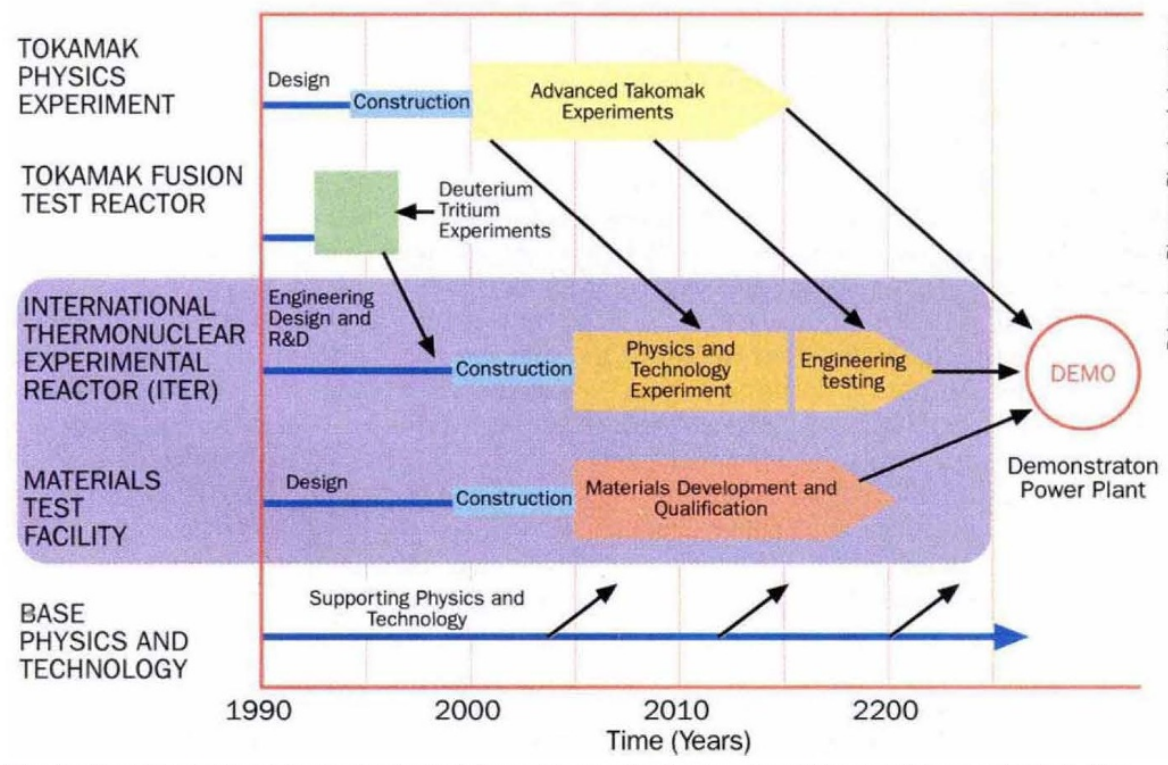

The United States' original strategy (above) to make fusion feasible must be curtailed, the Holdren panel says - but its "most indispensable elements" can be retained.

\section{NIH review to suggest streamlined handling of gene therapy bids}

Washington. An external advisory panel has provisionally concluded that the Recombinant DNA Advisory Committee (RAC) of the US National Institutes of Health (NIH) need not review human gene therapy protocols that are highly similar to protocols already approved.

Initial screening of applications would be made within the Office of Recombinant DNA Activities (ORDA) on the basis of standardized information that would be required with each application. This data would include the rationale for the trial, any similarities to other trials already approved by the RAC, details of the vector and its target cells, and criteria for patient selection.

ORDA itself would, after a preliminary review, pass directly to the Food and Drug Administration applications similar to protocols already approved by the RAC. Other completed applications would be scrutinized by the full RAC.

At a meeting last week in Bethesda, the panel of 11 non-NIH scientists also reached a preliminary conclusion that the current balance of the RAC, at least 14 of whose 25 members must be scientists and at least six non-scientists, is correct, and that the number of scientists should not be increased.

The ad hoc review committee was created in March by Harold Varmus, the director of $\mathrm{NIH}$, to review the role and structure of the $\mathrm{RAC}$; it is due to make its final report by November. The panel, chaired by Inder Verma of the Salk Institute, in San Diego, is working in parallel to another group, chaired by Arno Motulsky of the University of Washington and Stuart Orkin of Harvard Medical School, which is looking at the entire NIH effort in gene therapy.

Verma points out that many researchers, such as gene therapy pioneer W. French Anderson, as well as representatives of the biotechnology industry, have argued that the RAC should only review proposals that break new ground.

But he says that many members of the review panel - as well as of RAC itself believe that most proposals for human genetic therapy should continue to be discussed in the kind of public forum that the $\mathrm{RAC}$ provides. Indeed, according to Verma, the panel has yet to agree on the broadest question before it, namely how the role of the RAC should evolve as experiments involving the genetically altered cells in humans become increasingly routine.

Many panel members, he says, are keen that the RAC should continue to evaluate the scientific quality of proposals that come before it, as well as anticipating the difficult policy issues likely to arise in the relatively near future.

Robert Taylor 